\title{
Development and standarization of Kharodi fortified with Ragi flour
}

\author{
V.J. Netke, D.T. Bornare, P.R. Vairagar and K.P. Babar
}

Received : 26.07.2018; Revised : 21.08.2018; Accepted : 07.09.2018

See end of the Paper for authors' affiliation Correspondence to :

\section{V.J. Netke}

Department of Agricultural Engineering, Maharashtra Institute of Technology, Aurangabad (M. S.) India

Email : netkevaibhav333@

gmail.com
- ABSTRACT : Present work have been undertaken to develop and standerize the Ragi fortified Kharodi. The Kharodi is prepared from pearl milet with fortitfication of Ragi. Four treatment were used with sample code $\mathrm{T}_{0}(100-00), \mathrm{T}_{1}(70-30), \mathrm{T}_{2}(60-40)$ and $\mathrm{T}_{3}(50-50)$ i.e. 30,40 and 50 per cent are the per cent of the fortification. The prepared Ragi fortified Kharodi was evaluated for the its sensory acceptability using 9 point hedonic scale. It was found that treatment $\mathrm{T}_{1}$ containing 30 per cent Ragi fortified in Kharodi got highest score as compare to other treatments. Hence this preparation was used for further study of nutritional analysis and its found better result. It was concluded that from the research Ragi fortified Kharodi sample $\mathrm{T}_{1}$ containing 30 per cent of Ragi flour was most desirable in terms of sensory and nutritional quality profile.

- KEY WORDS : Kharodi, Sensory evolution, Pearl millet, Ragi

- HOW TO CITE THIS PAPER : Netke, V.J., Bornare, D.T., Vairagar, P.R. and Babar, K.P. (2018). Development and standarization of Kharodi fortified with Ragi flour. Internat. J. Agric. Engg., 11(2) : 346-352, DOI: 10.15740/HAS/IJAE/11.2/346-352. Copyright@2018: Hind Agri-Horticultural Society. 